\title{
Why Do Dialysis Patients Develop a Heart of Stone and Bone of China?
}

\author{
Leena Martola Peter Barany Peter Stenvinkel \\ Division of Renal Medicine, Department of Clinical Science, Karolinska University Hospital, Karolinska Institutet, \\ Stockholm, Sweden
}

\section{Key Words}

Adynamic bone disease $\cdot$ Calcification, arteries and heart valves - Calcification process, uremic risk factors - End-stage renal disease $\cdot$ Mineral metabolism disturbances · Osteogenesis - Vascular calcification • Inflammation

\begin{abstract}
Vascular calcification is a common complication of endstage renal disease (ESRD). The mechanisms responsible are complex and have so far been considered to be mainly the result of a passive mechanism due to elevated $\mathrm{PO}_{4}$ levels and high $\mathrm{Ca} \times \mathrm{PO}_{4}$ ion product resulting in saturated plasma. However, recent results suggest that also other features, commonly observed in the uremic milieu, such as chronic inflammation, hyperleptinemia and a dysregulation of various mineral-regulating proteins might also contribute to an enhanced calcification process. Moreover, as an inverse relationship between vascular calcification and bone density has been documented in ESRD, it could be speculated that pathologically low bone remodelling (adynamic bone disease) associated with active vitamin $\mathrm{D}$ treatment and low parathyroid hormone (PTH) levels may predispose to ectopic calcification of vessels, valves and heart. As patients with vascular calcification have a higher intake of calciumcontaining $\mathrm{PO}_{4}$ binders, novel, non-calcium containing $\mathrm{PO}_{4}$ binders may diminish the risk of progressive vascu-
\end{abstract}

lar calcification in this patient group. Further studies are needed to elucidate the respective role of chronic inflammation, hyperleptinemia and PTH-lowering therapies in this fatal complication of ESRD.

Copyright $\subset 2005$ S. Karger AG, Basel

\section{Introduction}

No doubt, patients with end-stage renal disease (ESRD) are subjected to a process of accelerated atherogenesis and show a high prevalence of atherosclerotic plaques in their coronary vessels [1]. In fact, as the risk of cardiovascular events in a 30 -year-old patient receiving dialysis is more than 100-fold higher than in the general population [2], the mortality of dialysis patients with cardiovascular problems is similar to that of many cancer patients with metastases. As traditional risk factors such as hypertension, dyslipidemia and diabetes mellitus can only partially explain the extent and severity of cardiovascular complications in this patient group, much recent interest has focused on non-traditional risk factors, such as inflammation, oxidative stress, and hyperphosphatemia, all common phenomena in the ESRD population [1].

During the last decade there has been a shift in the perception of the pathogenesis of vascular disease in man [3]. As only about half of patients having an acute coronary event are identified on the basis of traditional Fra-

\section{KARGER \\ Fax +4161306 1234 E-Mail karger@karger.ch} www.karger.com
(C) 2005 S. Karger AG, Basel 0253-5068/05/0233-0203\$22.00/0

Accessible online at: www.karger.com/bpu
Peter Stenvinkel, MD, PhD

Department of Renal Medicine K56, Karolinska Institutet

Karolinska University Hospital at Huddinge

SE-141 86 Stockholm (Sweden)

Tel. +4685858 2532, Fax +4687114742, E-Mail peter.stenvinkel@klinvet.ki.se 
mingham risk factors, additional risk factors for vascular disease need to be identified. It is therefore of interest that results from various follow-up population studies (e.g., HOPE, ARIC, HOT, and the Framingham Heart Study) indicate that renal insufficiency is a cardiovascular risk factor, independent of hypertension, diabetes mellitus or albuminuria [4]. Moreover, two recent large studies have

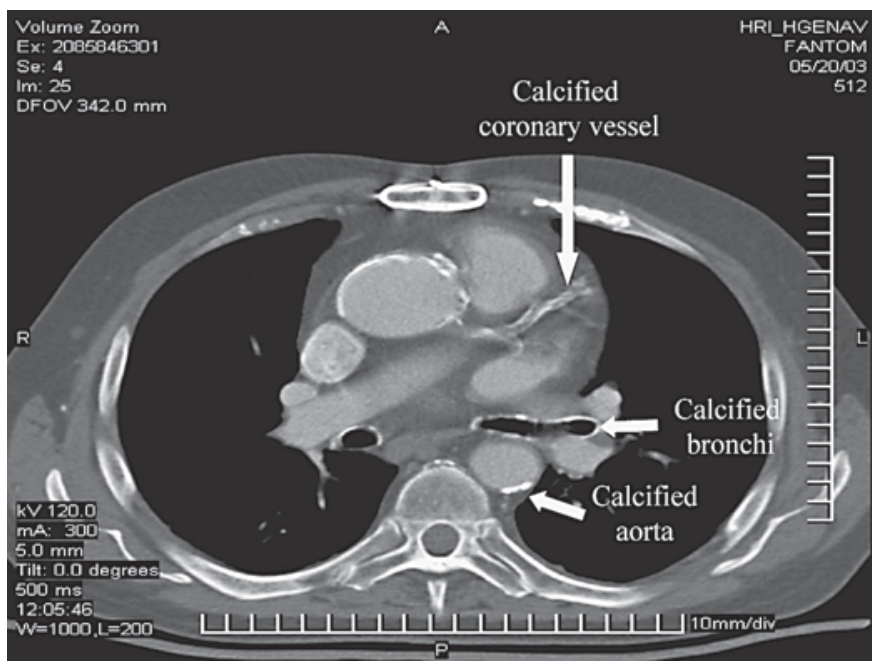

Fig. 1. A multislice spiral CT of the heart of a 67-year-old male HD patient showing extensive patchy calcifications (indicated by arrows) of coronary vessels, aorta and the main bronchi. demonstrated that even mild renal dysfunction should be considered as a major risk factor for cardiovascular disease (CVD) [5, 6]. This is important new information because almost $10 \%$ of a population with low risk and up to $30 \%$ of a population with high risk for CVD have signs of moderate renal insufficiency [4]. Both moderate [7] and severe renal insufficiency [8] are associated with an increased prevalence of inflammation, a well-known risk factor for CVD [9].

\section{Calcification of Arteries and Heart Valves Are Commonly Observed in ESRD}

Vascular calcification is a common phenomenon, increases with age and is present in most subjects aged over 65 years. However, in chronic renal insufficiency, advanced extraosseous calcification is present at a significantly earlier age (fig. 1). Goodman et al. [10] used electron beam computed tomography to demonstrate a high prevalence of coronary artery calcification among young adults receiving dialysis, especially those who had been on dialysis for more than 10 years. Subsequent studies have confirmed these findings and established that vascular calcifications are associated both with clinical symptoms of CVD [11] and cardiovascular mortality [12]. Whereas calcification of mitral and aorta valves occurs in less than $5 \%$ individuals in the normal population, the

Fig. 2. Potential causes of vascular calcifica-

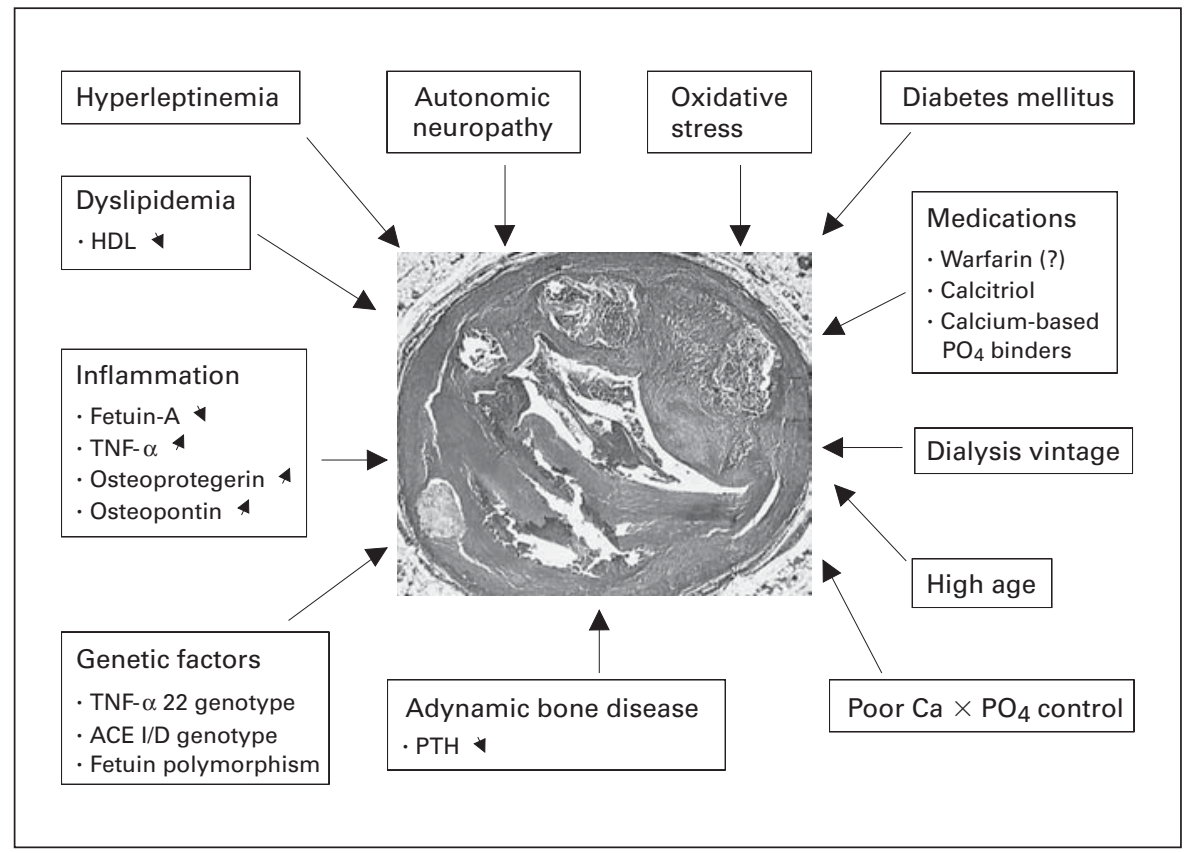
tion in ESRD. 
prevalence in dialysis patients is remarkably higher, 45 and $34 \%$, respectively [11]. As in the general population, the degree of cardiac valve calcification predicts cardiovascular morbidity and mortality also in dialysis patients [13]. Vascular calcification in ESRD has for a long time been considered to be the result of a passive process due to elevated $\mathrm{PO}_{4}$ levels and a high $\mathrm{Ca} \times \mathrm{PO}_{4}$ ion product. However, recent results suggest that also a number of factors other than disturbances in $\mathrm{Ca}$ and $\mathrm{PO}_{4}$ metabolism promote the deposition of minerals in body tissues (fig. 2).

\section{Vascular Calcification Resembles Osteogenesis}

The tunica media of arteries in uremic patients is significantly thicker and lumen considerably smaller (socalled pipe-stem appearance) compared to patients without renal failure [14]. These circumstances are corroborated by animal experiments and may explain why ESRD patients have a high incidence of re-occlusion after coronary angioplasty compared to other patient groups [15]. In gene-modified mice (ApoE knockout mice, which are in particular disposed to CVD) a slight renal insufficiency increases the size of already existing atherosclerotic plaques [16]. Interestingly, the process of vascular calcification in uremic patients seems to be similar to the osteoblastic differentiation in bone development [17]. Thus, bone-related proteins, such as osteopontin (OPN), matrix Gla protein (MGP) and bone morphogenetic protein (BMP), have been identified in calcified arteries [14]. Furthermore, high $\mathrm{PO}_{4}$ levels promote osteoblastic differentiation in smooth muscle cells in vitro [18]. From these findings it could be hypothesized that the tunica media in arteries of ESRD patients resembles typical bone tissue. It should be noted that osteogenesis also occurs in the heart valves, following basically the same development as seen in vascular calcification [17].

\section{Disturbances in Mineral Metabolism Are Associated with Increased Vascular Calcification}

In ESRD patients, disturbed $\mathrm{Ca} \times \mathrm{PO}_{4}$ balance stimulates the parathyroid glands to produce more parathyroid hormone (PTH). It has been speculated that elevated PTH, by increasing intracellular calcium levels, induces calcification of various tissues [14]. However, the recent data of London et al. [19] does not support the hypothesis that hyperparathyroidism plays a direct role on the vascular calcification process. Indeed, as two large North American studies have demonstrated, a strong correlation between high $\mathrm{PO}_{4}$ levels and cardiovascular death, disorders in $\mathrm{Ca} \times \mathrm{PO}_{4}$ metabolism per se, seems to be capable of increasing the risk for CVD. By analyzing over 6,000 dialysis patients, Block et al. [20] found that over $70 \%$ of the patients had high $\mathrm{PO}_{4}$ levels $(>1.6 \mathrm{mmol} / \mathrm{l})$, and mortality increased significantly with serum $\mathrm{PO}_{4} \mathrm{lev}-$ els $>2.1 \mathrm{mmol} / 1$. In this study, the high cardiovascular mortality with hyperphosphatemia was independent of PTH [20]. In an additional registry study from the USA, including almost 13,000 patients, an association of elevated serum $\mathrm{PO}_{4}$, high $\mathrm{Ca} \times \mathrm{PO}_{4}$ product and $\mathrm{PTH}$ with cardiac mortality risk was demonstrated in chronic HD patients [21]. It is notable that also in non-renal patients a correlation between hyperphosphatemia and calcification of cardiac valves has been demonstrated [22]. As dialysis patients with vascular calcification have a documented higher daily calcium intake from calcium-based $\mathrm{PO}_{4}$ binders than patients without calcification [10, 23], it has been suggested that treatment with calcium-based $\mathrm{PO}_{4}$ binders may actually be a significant risk factor for progressive vascular calcification and premature CVD. As 1,25-dihydroxyvitamin $\mathrm{D}_{3}$ levels correlate with the extent and progression of vascular calcification [24], vitamin D supplementation may also be a risk factor for vascular calcification. Indeed, Teng et al. [25] observed that paricalcitol (a new vitamin D analogue) treatment in longterm HD patients was associated with a significant survival advantage compared to those receiving calcitriol.

\section{Is Adynamic Bone Disease a Risk Factor for Vascular Calcification?}

Lower PTH levels characterize low bone turnover (adynamic bone disease) and as the bone is unable to buffer excess $\mathrm{Ca}$ and $\mathrm{PO}_{4}$ this may allow $\mathrm{Ca} \times \mathrm{PO}_{4}$ deposition in extraosseous tissues. Although an inverse relationship between vascular calcification and bone density was demonstrated already 1996 [26], the complex relationship(s) between bone mass and the vascular calcification process has not been extensively studied in uremic patients. In the general population, the progression of atherosclerotic calcification seems to be associated with increased bone loss in women during menopause [27]. As London et al. [28] recently demonstrated that patients with the highest calcification scores had the lowest PTH levels, it could be speculated that this hormone 
plays an important role in this scenario. Indeed, in the diabetic LDL receptor-deficient mice, PTH supplementation (teriparatide) inhibited vascular calcification and aortic osteogenic differentiation via direct effects on OPN [29]. Thus, as a low PTH level is associated with vascular calcification [19] and predicts mortality [30, 31], it could be speculated that adynamic bone disease may be a significant risk factor for accelerated atherogenesis in ESRD. This hypothesis is corroborated by findings in dialyzed diabetic patients, a group of patients with extensive vascular calcification (see below), in which impaired PTH secretion is a major mechanism of low bone turnover [32]. Moreover, in a recent study of 515 prevalent dialysis patients, Stevens et al. [33] demonstrated that the combination of low PTH with high $\mathrm{Ca} \times \mathrm{PO}_{4}$ was associated with the highest risk of mortality. Clearly, as pro-inflammatory cytokines promote both accelerated atherogenesis [34] and bone disease [35], further studies are needed to evaluate the role of persistent inflammation in this scenario. Indeed, it has been hypothesized that uremic cytokines and/or toxic metabolites may contribute to a form of bone disease, indistinguishable from adynamic bone disease, but with increased osteoclastic bone resorption [36].

\section{Inflammation May Promote Vascular Calcification}

Although abnormal mineral metabolism may be the most important risk factor for increased vascular calcification in uremia, recent studies suggest that also a chronic inflammatory response stimulates the process of calcification [37]. A cross-sectional study by Wang et al. [38] in CAPD patients indicated that calcification of coronary arteries and cardiac valves are not only associated to age and $\mathrm{Ca} \times \mathrm{PO}_{4}$ balance, but also to the incidence of malnutrition and inflammation. In addition, correlations between inflammation and diffuse coronary artery calcification [39] and aortic valve alteration [40] have been documented in HD patients. As other chronically inflamed patient groups, such as SLE patients [41], have increased coronary calcification, this also suggests a direct link between vasculopathy and inflammatory activity. Although it is not exactly known how chronic inflammation contributes to increased vascular calcification, various mechanisms have been proposed. Indeed, several of the factors that may promote or inhibit the calcification process are associated to inflammation (table 1). Ketteler et al. [42] have recently presented an interesting hypothesis on how
Table 1. Factors that have been shown to inhibit or promote the calcification process

Factors Associated to inflammation

Factor-inhibiting calcification

Osteoprotegerin [48]

Osteopontin [50]

Bone morphogenic protein-7 [79]

Fetuin-A [42]

HDL cholesterol [58]

Matrix Gla protein [45]

Factor-promoting calcification

Calcitriol [24]

Leptin [54]

Tumor necrosis factor- $\alpha$ [47]

Genetic factors [43]

Diabetes mellitus [62]

inflammation may promote atherosclerosis in ESRD. They studied circulating plasma levels of $\alpha_{2}$-HeremansSchmid glycoprotein (fetuin), a negative acute-phase protein preventing calcification process and demonstrated that low levels of fetuin predicted cardiovascular complications in prevalent HD patients. We have recently confirmed these findings in ESRD patients starting dialysis treatment and found that low fetuin levels independently predicted both all-cause and cardiovascular mortality rate [43]. MGP is a fetuin-like compound that serves as a tissue-bound inhibitor of calcification. Like the fetuin-A knockout mice [44], MGP knockout mice also show extreme generalized medial vascular calcification and die of premature vascular disease [45]. Clinical data also support a significant role of MGP. As an example, Jono et al. [46] have documented an inverse relation between MGP levels and severity of coronary artery calcification in 115 patients with coronary artery disease. As the calcification inhibitory effect of MGP is dependent on vitamin $\mathrm{K}$, it has been speculated that warfarin treatment may contribute to an accelerated process of vascular calcification. However, to the best of our knowledge, the putative proatherogenic role of warfarin has not yet been evaluated in clinical studies.

As the process of calcification includes monocyte and macrophage infiltration, the release of another pro-inflammatory cytokine, TNF- $\alpha$, may also take part in vascular calcification by promoting osteoblastic differentiation through the cAMP pathway [47]. Osteoprotegerin (OGP) is another member molecule of the TNF-receptor 
family, which may play a central role in the regulation of bone turnover and in calcification processes at extraosseous sites. As OGP knockout animals develop both osteoporosis and significant calcifications of aorta and renal arteries [48], it could be hypothesized that decreased availability of this decoy receptor of RANKL may contribute to extraosseous calcification. On the other hand, as serum OPG levels were significantly elevated in HD patients with a higher aortic calcification index, it could be speculated that increased serum levels of OPG may be a compensatory protective response to the progression of vascular calcification [49]. Moe et al. [50] have demonstrated that vascular calcification of the medial layer of epigastric arteries is associated with deposition of the bone matrix protein OPN in ESRD patients undergoing renal transplantation. These data are corroborated by recent findings by Ström et al. [51] in triple knockout mice (ApoE/LDL receptor/OPN) showing that OPN deficiency reduces atherogenesis.

\section{Role of Other Uremic Risk Factors in the Calcification Process}

Leptin, an adipokine often markedly increased in uremic patients [52] and associated to inflammation [53], has also been shown to stimulate the process of calcification [54]. In accordance, a recent study in type-2 diabetic patients demonstrated that plasma leptin levels were associated with coronary atherosclerosis after controlling for both adiposity and CRP [55]. As leptin is a powerful inhibitor of bone formation [56, 57], a reduced bone turnover may be one mechanism by which this adipokine promotes extraosseous calcification. As HDL-cholesterol regulate osteoblastic differentiation and calcification of vascular cells [58], also lipids may play an important role in the calcification process. Oxidative stress is another frequent phenomenon in ESRD which is associated to both inflammation and endothelial dysfunction [1]. Since oxidative stress appears to play an important modulating role in the development of vascular calcification in vitro [59], it is of interest that two placebo-controlled studies have shown a reduction of cardiovascular events in dialysis patients on vitamin E [60] and acetylcysteine [61]. Based on these results, larger trials that are sufficiently powered to assess the effects of antioxidant treatment strategies on mortality appear highly desirable in ESRD patients.

Vascular calcification [62] and adynamic bone disease [63] are particularly common features in patients with diabetes mellitus - a group of patients having a high prevalence of both inflammation and increased oxidative stress $[64,65]$. As the diabetic type of calcification is an active cell-mediated process where smooth muscle cells in blood vessels express a great number of bone matrix proteins regulating the calcification [62], it may be similar to the process observed in ESRD. Although poor control of $\mathrm{Ca} \times \mathrm{PO}_{4}$ may also be an important contributor of vascular calcification in diabetic ESRD patients, Ishimura et al. [66] have demonstrated that poor glycemic control remains a critical factor. Moreover, since neuropathy seems to be a significant risk factor for the development of vascular calcification in diabetic patients [62], studies are necessary to investigate the role of autonomic neuropathy in the process of uremic calcification.

\section{Prevention and Treatment of Vascular Calcification in ESRD}

Although we have now begun to recognize the associations between disturbed mineral metabolism, inflammation and excessive vascular calcification in ESRD, the recommendations given for its treatment are not well recognized. As hyperphosphatemia is an independent risk factor for CVD in this patient group, a main objective should be to adjust $\mathrm{PO}_{4}$ levels and $\mathrm{Ca} \times \mathrm{PO}_{4}$ balance. Diet restrictions should be avoided since limitations in $\mathrm{PO}_{4}$ intake often lead to simultaneous low protein intake and risk of malnutrition. Lower $\mathrm{Ca}$ concentration in dialysate could be considered since it can reduce the risk for hypercalcemia, particularly in conjunction with treatment with active vitamin $\mathrm{D}$ and/or calcium-based $\mathrm{PO}_{4}$ binders. Preference may also be given to hemodiafiltration as it removes $\mathrm{PO}_{4}$ better than routine HD [67]. Daily dialysis may be yet another way of improving $\mathrm{PO}_{4}$ balance in well-motivated HD patients [68]. Finally, early transplantation in appropriate patient groups should be encouraged as dialysis vintage seems to enhance vascular calcification and mortality [69].

Despite these implements, a majority of dialysis patients will need treatment with $\mathrm{PO}_{4}$ binders. Ever since nephrologists abandoned the use of aluminium-based phosphate binders during the 1980s (in order to diminish the risk for aluminium accumulation), an assortment of oral calcium salts has been used for the control of hyperphosphatemia. Calcium-based $\mathrm{PO}_{4}$ binders have been considered to be harmless with only moderate side effects (i.e. moderate hypercalcemia and gastrointestinal problems). However, since these preparations may promote 
vascular calcification, new treatment guidelines from the USA (K-DOQI) suggest a radical shift away from calcium usage and recommend that the total $\mathrm{Ca}$ intake, including both nutritional $\mathrm{Ca}$ as well as calcium-based $\mathrm{PO}_{4}$ binders, should not exceed 2,000 mg/day [70]. Thus, non-calciumbased binders should be preferred in patients with severe vascular or soft tissue calcifications. The novel non-calcium-, non-aluminium-containing $\mathrm{PO}_{4}$ binder sevelamer has been shown to diminish the risk for vascular calcification in dialysis patients $[71,72]$ and may be an alternative for patients with $\mathrm{PO}_{4}$ retention. Experiments on rats with renal insufficiency have demonstrated that sevelamer is more effective than calcium carbonate to prevent progression of renal insufficiency and the accumulation of calcium in kidneys [73]. Moreover, as sevelamer has favorable effects on lipids [74], it could be speculated that sevelamer, like other lipid-lowering drugs [75], may have anti-inflammatory effects. However, sevelamer is expensive and has relatively moderate $\mathrm{PO}_{4}$-binding capacity, and sometimes it needs to be combined to various $\mathrm{Ca}$ salts in able to reach normal $\mathrm{PO}_{4}$ levels.

In addition to effective vitamin D analogues controlling PTH production without inducing hypercalcemia, new and more effective, non-calcium-containing $\mathrm{PO}_{4}$ binders (such as lanthanum chloride and ferric chloride) will soon be introduced for clinical use. The importance of maintenance of some PTH activity (150-300 ng/l), reflecting active bone turnover, should be pointed out since low PTH with high $\mathrm{Ca}$ and $\mathrm{PO}_{4}$ values is associated with higher mortality [30, 31]. As adynamic bone disease may be related to vascular calcification [19], interventions associated with excessive lowering of parathyroid activity (such as parathyroidectomy and treatment strategies that increase the Ca balance) may be a risk factor for excessive arterial calcification. Indeed, one study demonstrated that vascular calcification was more often observed in ESRD patients after parathyroidectomy [28]. In this context the new calcium-receptor-stimulating calcimimetics are of outmost interest, as these drugs seem to have a direct controlling effect on parathyroid gland by adjusting both $\mathrm{PTH}$ and $\mathrm{Ca} \times \mathrm{PO}_{4}$ product [76]. The role of other potential treatment strategies to prevent vascular calcification in ESRD, such as biphosphonates and calcium channel blockers, have recently been discussed [77].

Since there is clinical evidence suggesting an association between a chronic inflammatory response and widespread vascular calcification, it seems advisable to investigate and treat inflammation aggressively in ESRD patients. Obvious signs of chronic infectious process, such as tooth and foot infections, should be searched for and properly treated. Other conceivable causes for chronic inflammatory reaction, as rheumatic diseases, hypervolemia, dialysis with bioincompatible membranes, should be considered and, if possible, adjusted. However, from our experience there is seldom any real established reason for chronic inflammation in ESRD patients. It has been suggested that patients with constantly elevated CRP should be evaluated for silent coronary disease [78]. Numerous drugs, which currently have other indications than inflammation, i.e. statins, ACE inhibitors, glitazones and antioxidants, have significant anti-inflammatory effects [1]. Future placebo-controlled studies will show if these medicines and/or targeted anticytokine treatment strategies can be suitable alternatives for the treatment of the inflamed dialysis patient. Finally, as studies on LDLreceptor null mice have shown that BMP-7 (maintains renal tubular differentiation in the adult and is downregulated in renal failure) is effective in treating vascular calcifications [79], further investigations are needed to demonstrate whether this renal morphogen and cytokine repressor [80] may be a potential future treatment strategy in renal patients with vascular calcification.

In summary, extraosseous calcification of coronary arteries and heart valves is a common phenomenon in ESRD and predicts both cardiovascular events and premature death. Recent evidence suggests that associations exist between disturbed mineral metabolism, chronic inflammation, adynamic bone disease and vascular calcification in ESRD. Hopefully, future studies will reveal if targeted early intervention of these risk factors in dialysis patients may prevent the fatal development of a heart of stone and a bone of China. 


\section{References}

1 Stenvinkel P, Pecoits-Filho R, Lindholm B: Coronary artery disease in end-stage renal disease - No longer a simple plumbing problem. J Am Soc Nephrol 2003;14:1927-1939.

-2 Foley RN, Parfrey PS, Sarnak MJ: Clinical epidemiology of cardiovascular disease in chronic renal failure. Am J Kidney Dis 1998;32(suppl 5):112-119.

-3 Ross R: Atherosclerosis: An inflammatory disease. N Engl J Med 1999;340:115-126.

-4 Mann JF, Gerstein HC, Dulau-Florea I, Lonn E: Cardiovascular risk in patients with mild renal insufficiency. Kidney Int 2003;63(suppl 84):192-196.

5 Anavekar NS, McMurray JJ, Velazquez EJ, Solomon SD, Kober L, Rouleau JL, et al: Relation between renal dysfunction and cardiovascular outcomes after myocardial infarction. $\mathrm{N}$ Engl J Med 2004;351:1285-1295.

-6 Go AS, Chertow GM, Fan D, McCulloch CE, Hsu CY: Chronic kidney disease and the risks of death, cardiovascular events, and hospitalization. N Engl J Med 2004;351:1296-1305.

7 Shlipak MG, Fried LF, Crump C, Bleyer AJ, Manolio TA, Tracy RP, et al: Elevations of inflammatory and procoagulant biomarkers in elderly persons with renal insufficiency. Circulation 2003;107:87-92.

-8 Zimmermann J, Herrlinger S, Pruy A, Metzger $\mathrm{T}$, Wanner C: Inflammation enhances cardiovascular risk and mortality in hemodialysis patients. Kidney Int 1999;55:648-658.

$\checkmark$ Libby P: Inflammation in atherosclerosis. Nature 2002;420:868-874.

- 10 Goodman WG, Goldin J, Kuizon BD, Yoon C, Gales B, Sider D, et al: Coronary-artery calcification in young adults with end-stage renal disease who are undergoing dialysis. N Engl J Med 2000;342:1478-1483.

11 Raggi P, Boulay A, Chasan-Taber S, Amin N, Dillon M, Burke SK, et al: Cardiac calcification in adult hemodialysis patients. J Am Coll Cardiol 2002;39:695-701.

12 Blacher J, Guerin AP, Pannier B, Marchais SJ, London GM: Arterial calcifications, arterial stiffness and cardiovascular risk in end-stage renal disease. Hypertension 2001;38:938942.

13 Otto CM, Lind BK, Kitzman DW, Gersh BJ, Siscovick DS: Association of aortic-valve sclerosis with cardiovascular mortality and morbidity in the elderly. N Engl J Med 1999;341: 142-147.

14 Cozzolino M, Dusso AS, Slatopolsky E: Role of calcium-phosphate product and bone-associated proteins on vascular calcification in renal failure. J Am Soc Nephrol 2001;12:25112516.

-15 Reusser LM, Osborn LA, White HJ, Sexson R, Crawford MH: Increased morbidity after coronary angioplasty in patients in chronic hemodialysis. Am J Cardiol 1994;73:965-967.
16 Buzello M, Tornig J, Faulhaber J, Ehmke H, Ritz E, Amann K: The apolipoprotein E knockout mouse: A model documenting accelerated atherogenesis in uremia. J Am Soc Nephrol 2003;14:311-316.

17 Mohler ER, Gannon F, Reynolds C, Zimmermann R, Keane MG, Kaplan FS: Bone formation and inflammation in cardiac valves. Circulation 2001;103:1522-1528.

18 Jono S, McKee MD, Murry CE, Shioi A, Nushuzawa Y, Mori K, et al: Role of calciumphosphate product and bone-associated proteins on vascular calcification in renal failure. Circ Res 2000;87:E10-E17.

19 London GM, Marty C, Marchais SJ, Guerin AP, Metivier F, de Vernejoul MC: Arterial calcifications and bone histomorphometry in endstage renal disease. J Am Soc Nephrol 2004; 15 : 1943-1951.

20 Block GA, Hulbert-Shearon TE, Levin NW, Port FK: Association of serum phosphorus and calcium $\times$ phosphate product with mortality risk in chronic hemodialysis patients: A national study. Am J Kidney Dis 1998; 31:607617.

21 Ganesh SK, Stack AG, Levin N, HulbertShearon T, Port FK: Association of elevated serum $\mathrm{PO}_{4}, \mathrm{Ca} \times \mathrm{PO}_{4}$ product and parathyroid hormone with cardiac mortality risk in chronic hemodialysis patients. J Am Soc Nephrol 2001;12:2131-2138.

22 Fitzpatrick LA, Severson A, Edwards WD, Ingram RT: Diffuse calcification in human coronary arteries. Association of osteopontin with atherosclerosis. J Clin Invest 1994;94:15971604.

23 Chertow GM, Raggi P, Chasan-Taber S, Bommer J, Holzer H, Burke SK: Determinants of progressive vascular calcification in haemodialysis patients. Nephrol Dial Transplant 2004; 19:1489-1496.

24 Jono S, Nishizawa Y, Shioi A, Morii H: 1,25Dihydroxyvitamin $\mathrm{D}_{3}$ increases in vitro vascular calcification by modulating secretion of endogenous parathyroid hormone-related peptide. Circulation 1998;98:1302-1306.

25 Teng M, Wolf M, Lowrie E, Ofsthun N, Lazarus JM, Thadhani R: Survival of patients undergoing hemodialysis with paricalcitol or calcitriol therapy. N Engl J Med 2003;349: 446-456.

26 Braun J, Oldendorf M, Moshage W, Heidler F, Zeitler E, Luft FC: Electron beam computed tomography in the evaluation of cardiac calcification in chronic dialysis patients. Am J Kidney Dis 1996;27:394-401.

27 Hak AE, Pols HA, van Hemert AM, Hofman A, Witteman JC: Progression of aortic calcification is associated with metacarpal bone loss during menopause: A population-based longitudinal study. Arterioscler Thromb Vasc Biol 2000;20:1926-1931.
28 London GM, Guerin AP, Marchais SJ, Metivier F, Pannier B, Adda H: Arterial media calcification in end-stage renal disease: Impact on all-cause and cardiovascular mortality. Nephrol Dial Transpl 2003;18:1731-1740.

29 Shao JS, Cheng SL, Charlton-Kachigian N, Loewy AP, Towler DA: Teriparatide (human parathyroid hormone (1-34)) inhibits osteogenic vascular calcification in diabetic low density lipoprotein receptor-deficient mice. J Biol Chem 2003;278:50195-50202.

30 Guh JY, Chen HC, Chuang HY, Huang SC, Chien LC, Lai YH: Risk factors and risk for mortality of mild hypoparathyroidism in hemodialysis patients. Am J Kidney Dis 2002;39: 1245-1254.

- 31 Avram MM, Mittman N, Myint MM, Fein P: Importance of low serum intact parathyroid hormone as a predictor of mortality in hemodialysis and peritoneal dialysis patients: 14 years of prospective observation. Am J Kidney Dis 2001;38:1351-1357.

32 Inaba M, Nagasue K, Okuno S, Ueda M, Kumeda $Y$, Imanishi $Y$, et al: Impaired secretion of parathyroid hormone, but not refractoriness of osteoblast, is a major mechanism of low bone turnover in hemodialyzed patients with diabetes mellitus. Nephrol Dial Transplant 2002;39:1261-1269.

- 33 Stevens LA, Djurdjev O, Cardew S, Cameron EC, Levin A: Calcium, phosphate, and parathyroid hormone levels in combination and as a function of dialysis duration predict mortality: Evidence for the complexity of the association between mineral metabolism and outcomes. J Am Soc Nephrol 2004;15:770-779.

34 Stenvinkel P, Heimbürger O, Jogestrand T: Elevated interleukin- 6 predicts progressive carotid atherosclerosis in dialysis patients: Association to Chlamydia pneumoniae seropositivity. Am J Kidney Dis 2002;39: 274-282.

- 35 Moffett SP, Zmuda JM, Cauley JA, Stone KL, Nevitt MC, Ensrud KE, et al: Association of the G-174C variant in the interleukin-6 promoter region with bone loss and fracture risk in older women. J Bone Miner Res 2004;19: 1612-1618.

36 Gal-Moscovici A, Popovtzer MM: Parathyroid hormone-independent osteoclastic resorptive bone disease: A new variant of adynamic bone disease in haemodialysis patients. Nephrol Dial Transplant 2002; 17:620-624.

37 Stenvinkel P, Ketteler M, Johnson RJ, Lindholm B, Pecoits-Filho R, Riella M, et al: IL-10, IL-6 and TNF- $\alpha$ : Central factors in the altered cytokine network of uremia - the good, the bad, and the ugly. Kidney Int 2005;67:12161233.

38 Wang A, Wang M, Woo J, Lam C, Li P, Lui $\mathrm{SF}$, et al: Cardiac valve calcification as an important predictor for all-cause mortality and cardiovascular mortality in long-term peritoneal dialysis patients. J Am Soc Nephrol 2003; 14:159-168. 
>39 Oh J, Wunsch R, Turzer M, Bahner M, Raggi $\mathrm{P}$, Querfeld U, et al: Advanced coronary and carotid arteriopathy in young adults with childhood-onset chronic renal failure. Circulation 2002;106:100-105.

40 Schonenberger A, Winkelspecht B, Kohler H, Girndt M: High prevalence of aortic valve alterations in haemodialysis patients is associated with signs of chronic inflammation. Nephron Clin Pract 2004;96:48-55.

-41 Asanuma Y, Oeser A, Shintani AK, Turner E, Olsen N, Fazio S, et al: Premature coronaryartery atherosclerosis in systemic lupus erythematosus. N Engl J Med 2003;249:2407-2415.

-42 Ketteler M, Bongartz P, Westenfeld R, Wildberger JE, Mahnken AH, Bohm R, et al: Association of low fetuin-A (AHSG) concentrations in serum with cardiovascular mortality in patients on dialysis: A cross-sectional study. Lancet 2003;361:327-333.

43 Stenvinkel P, Wang K, Qureshi AR, Axelsson J, Pecoits-Filho R, Gao P, et al: Low fetuin-A levels are associated with cardiovascular death: Impact of variations in the gene encoding fetuin. Kidney Int, in press.

-44 Schafer C, Heiss A, Schwarz A, Westenfeld R, Ketteler M, Floege J, et al: The serum protein $\alpha_{2}$-Heremans-Schmid glycoprotein/fetuin-A is a systemically acting inhibitor of ectopic calcification. J Clin Invest 2003; 112:357-366.

-45 Luo G, Ducy P, McKee MD, Pinero GJ, Loyer E, Behringer RR, et al: Spontaneous calcification of arteries and cartilage in mice lacking matrix GLA protein. Nature 1997;386:7881.

-46 Jono S, Ikari Y, Vermeer C, Dissel P, Hasegawa $\mathrm{K}$, Shioi A, et al: Matrix Gla protein is associated with coronary artery calcification as assessed by electron-beam computed tomography. Thromb Haemost 2004;91:790-794.

47 Tintut Y, Patel J, Parhami F, Demer LL: Tumor necrosis factor- $\alpha$ promotes in vitro calcification of vascular cells via the cAMP pathway. Circulation 2000;102:2636-2642.

-48 Bucay N, Sarosi I, Dunstan CR, Morony S, Tarpley J, Capparelli C, et al: Osteoprotegerindeficient mice develop early onset osteoporosis and arterial calcification. Genes Dev 1998;12: 1260-1268.

-49 Nitta K, Akaiba T, Uchida K, Kawashima A, Yumura W, Kabaya T, et al: The progression of vascular calcification and serum osteoprotegerin levels in patients on long-term hemodialysis. Am J Kidney Dis 2003;42:303-309.

$\checkmark 50$ Moe SM, O’Neill KD, Duan D, Ahmed S, Chen NX, Leapman SB, et al: Medial artery calcification in ESRD patients is associated with deposition of bone matrix proteins. Kidney Int 2002;61:638-647.

-51 Ström A, Franzen A, Wangnerud C, Knutsson AK, Heinegard D, Hultgardh-Nilsson A: Altered vascular remodeling in osteopontin-deficient atherosclerotic mice. J Vasc Res 2004;41: 314-322.
52 Nordfors L, Lonnqvist F, Heimburger O, Danielsson A, Schalling M, Stenvinkel P: Low leptin gene expression and hyperleptinemia in chronic renal failure. Kidney Int 1998;54: 1267-1275.

53 Shamsuzzaman AS, Winnicki M, Wolk R, Svatikova A, Phillips BG, Davison DE, et al: Independent association between plasma leptin and $\mathrm{C}$-reactive protein in healthy humans. Circulation 2004; 109:2181-2185.

54 Parhami F, Tintut Y, Ballard A, Fogelman AM, Demer LL: Leptin enhances the calcification of vascular cells: Artery wall as a target of leptin. Circ Res 2001;88:954-960.

55 Reilly MP, Iqbal N, Schutta M, Wolfe ML, Scally M, Localio AR, et al: Plasma leptin levels are associated with coronary atherosclerosis in type 2 diabetes. J Clin Endocrinol Metab 2004;89:3872-3878

56 Elefteriou F, Takeda S, Ebihara K, Magre J, Patano N, Kim CA, et al: Serum leptin level is a regulator of bone mass. Proc Natl Acad Sci USA 2004;101:3258-3263.

57 Zoccali C PV, Tripepi G, Cutrupi S, Pizzini P, Mallamaci F: Leptin and biochemical markers of bone turnover in dialysis patients. J Nephrol 2004; 17:253-260.

58 Parhami F, Basseri B, Hwang J, Tintut Y, Demer LL: High-density lipoprotein regulates calcification of vascular cells. Circ Res 2002;91 570-576.

59 Mody N, Parhani F, Sarafian TA, Demer LL: Oxidative stress modulates osteoblastic differentiation of vascular and bone cells. Free Radic Biol Med 2001;15:509-519.

60 Boaz M, Smetana S, Weinstein T, Matas Z, Gafter U, Iaina A, et al: Secondary prevention with antioxidants of cardiovascular disease in end-stage renal disease (SPACE): Randomised placebo-controlled trial. Lancet 2000;356: 1213-1218.

61 Tepel M, van der Giet M, Statz M, Jankowski J, Zidek W: The antioxidant acetylcysteine reduces cardiovascular events in patients with end-stage renal failure. Circulation 2003;107: 992-995.

62 Chen NX, Moe SM: Arterial calcification in diabetes. Curr Diab Rep 2003;3:28-32.

63 Yamamoto T, Ozono K, Miyauchi A, Kasayama S, Kojima Y, Shima M, et al: Role of advanced glycation end products in adynamic bone disease in patients with diabetic nephropathy. Am J Kidney Dis 2001;38:S161-S164.

64 Thorand B, Lowel H, Schneider A, Kolb H, Meisinger C, Frohlich M, et al: C-reactive protein as a predictor for incident diabetes mellitus among middle-aged men: Results from the MONICA Augsburg cohort study, 1984-1998. Arch Intern Med 2003;163:93-99.

65 Helmersson J, Vessby B, Larsson A, Basu S: Association of type 2 diabetes with cyclooxygenase-mediated inflammation and oxidative stress in an elderly population. Circulation 2004;109:1729-1734.
66 Ishimura E, Okuno S, Kitatani K, Kim M, Shoji T, Nakatani T, et al: Different risk factors for peripheral vascular calcification between diabetic and non-diabetic haemodialysis patients - Importance of glycaemic control. Diabetologia 2002;45:1446-1448.

67 Zehnder C, Gutzwiller JP, Renggli K: Hemodiafiltration - A new treatment option for hyperphosphatemia in hemodialysis patients. Clin Nephrol 1999;52:152-159.

68 Raj DS, Charra B, Pierratos A, Work J: In search of ideal hemodialysis: Is prolonged frequent dialysis the answer? Am J Kidney Dis 1999;34:597-610.

69 McCullough PA, Sandberg KR, Dumler F, Yanez JE: Determinants of coronary vascular calcification in patients with chronic kidney disease and end-stage renal disease: A systematic review. J Nephrol 2004;17:205-215.

70 Eknoyan G, Levin A, Levin NW: Bone metabolism and disease in chronic kidney disease. Am J Kidney Dis 2003;42:S1-S201.

71 Raggi P, Bommerm J, Chertow GM: Valvular calcification in hemodialysis patients randomized to calcium-based phosphorus binders or sevelamer. J Heart Valve Dis 2004;13:134141.

72 Chertow GM, Burke SK, Raggi P: Sevelamer attenuates the progression of coronary and aortic calcification in hemodialysis patients. Kidney Int 2002;62:245-252.

73 Cozzolino M, Dusso AA, Liapis H, Finch J, Lu Y, Burke SK, et al: The effects of sevelamer hydrochloride and calcium carbonate on kidney calcification in uremic rats. $\mathrm{J}$ Am Soc Nephrol 2002;13:2299-2308.

74 Chertow GM, Burke SK, Dillon M, Slatopolsky E: Long-term effects of sevelamer hydrochloride on the calcium $\times$ phosphate product and lipid profile of haemodialysis patients. Nephrol Dial Transplant 2000;15:559.

75 Chang JW, Yang WS, Min WK, Lee SK, Park JS, Kim SB: Effects of simvastatin on high-sensitivity C-reactive protein and serum albumin in hemodialysis patients. Am J Kidney Dis 2002;39:1213-1217.

76 Wada M, Nagano N: Control of parathyroid cell growth by calcimimetics. Nephrol Dial Transplant 2003;18(suppl 3):13-17.

77 Goldsmith D, Ritz E, Covic A: Vascular calcification: A stiff challenge for the nephrologist. Does preventing bone disease cause arterial disease? Kidney Int 2004;66:1315-1333.

78 Kim SB, Min WK, Lee SK, Park JS, Hong CD, Yang WS: Persistent elevation of C-reactive protein and ischemic heart disease in patients with continuous ambulatory peritoneal dialysis. Am J Kidney Dis 2002;39:342-346.

79 Davies MR, Lund RJ, Hruska KA: BMP-7 is an efficacious treatment of vascular calcification in a murine model of atherosclerosis and chronic renal failure. J Am Soc Nephrol 2003; 14:1559-1567.

80 Gould SE, Day M, Jones SS, Dorai H: BMP-7 regulates chemokine, cytokine, and hemodynamic gene expression in proximal tubule cells. Kidney Int 2002;61:51-60. 